\title{
Benzodiazepiner i epilepsibehandling
}

\author{
Ved epilepsi benyttes benzodiazepinene hovedsakelig for å stoppe \\ pågående anfall. Ved status epilepticus er intravenøs diazepam \\ førstehåndsmidlet i sykehus. Utenfor sykehus er rektal diazepam \\ i ferd med å bli erstattet av bukkal midazolam. Klonazepam, klobazam \\ og nitrazepam (til barn) blir noe brukt som tilleggspreparat for å fore- \\ bygge anfall.
}

Se også kunnskapsprøve på www.tidsskriftet.no/quiz

\section{Karl O. Nakken}

karl.otto.nakken@epilepsy.no

Elisif M. Rytter

Frans Brockmeier

Epilepsisenteret-SSE

Nevroklinikken

Oslo universitetssykehus, Rikshospitalet

Postboks 53

1306 Bærum postterminal

Benzodiazepiner er en samlebetegnelse på ca. 35 substanser med én eller to benzenringer og en sjukantet diazepinring. Sternbach utviklet dem i 1933 ut fra en gruppe heterosykliske substanser som hadde vært kjent siden 1891. De kom imidlertid ikke i klinisk bruk før i 1960-årene (1). Først ble de brukt som anxiolytika og sedativer, men fra 1965 har de også vært i bruk mot epilepsi. Gastaut og medarbeidere var de første som beskrev den svært gode effekten av diazepam ved status epilepticus (2). Det viste seg snart at stoffgruppen hadde bredspektrede antiepileptiske egenskaper med raskt innsettende effekt kombinert med lav toksisitet.

Benzodiazepinene har en unik virkningsmekanisme. Deres antiepileptiske egenskaper skyldes bindingen til $\mathrm{GABA}_{\mathrm{A}}$-reseptorkomplekset. De reduserer nevronenes eksitabilitet ved å forsterke den GABAerge inhibisjonen gjennom å øke GABAs evne til å åpne kloridkanalene i reseptoren (3). At benzodiazepinene har noe forskjellig effektog bivirkningsprofil, kan skyldes at de har noe ulike farmakokinetiske egenskaper og noe ulik affinitet til de $19 \mathrm{GABA}_{\mathrm{A}}$-reseptorsubenhetene (4).

Muligens påvirker benzodiazepinene også ionestrømmen gjennom natrium- og kalsiumkanalene (5).

\section{Materiale og metode}

Grunnlaget for denne artikkelen er et ikkesystematisk litteratursøk i PubMed med et skjønnsmessig utvalg av artikler og forfatternes egne erfaringer innen feltet.

\section{Anfallskupering i sykehus}

Status epilepticus er en svært alvorlig tilstand med mange ulike årsaker. Varer den utover 30-60 minutter, er den forbundet med en betydelig morbiditet og mortalitet. I fagmiljøet har det vært uenighet om hvor lenge anfallsaktiviteten skal ha vart før man kan bruke betegnelsen "status epilepticus», men alle er enige om viktigheten av tidlig intervensjon.

Ved serieanfall og status epilepticus, både av konvulsiv og ikke-konvulsiv type, samt anfall ved anoksisk hjerneskade, er 10-20 $\mathrm{mg}$ diazepam (Stesolid) gitt intravenøst som en bolusdose $(2-5 \mathrm{mg} / \mathrm{min})$ førstelinjebehandling hos voksne ved de fleste norske sykehus. Hos barn med en slik vedvarende anfallsaktivitet gis gjerne $0,5-1,0 \mathrm{mg}$ diaze$\mathrm{pam} / \mathrm{kg}$ intravenøst (maksimalt $10 \mathrm{mg}$ ).

I enkelte andre land, bl.a. i USA, er lorazepam, $4 \mathrm{mg}$ gitt intravenøst til voksne og $0,1 \mathrm{mg} / \mathrm{kg}$ til barn, førstevalget ved slike tilstander. Lorazepam er mindre fettløselig enn diazepam, passerer blod-hjerne-barrieren langsommere og har lengre virkningstid (6).

\section{Anfallskupering utenfor sykehus}

For å stoppe enkeltanfall som varer mer enn 4-5 minutter, serieanfall eller status epilepticus har det utenfor sykehus i mange år vært vanlig å bruke diazepam (Stesolid) rektalvæske. Voksne har gjerne fått $20 \mathrm{mg}$, barn $0,5 \mathrm{mg} / \mathrm{kg}$. Hvis anfallene ikke har stoppet etter ti minutter, har voksne som oftest fått ytterligere $30 \mathrm{mg}$ rektalt, mens barn har fått samme dosering en gang til.

Det er imidlertid flere ulemper med denne behandlingsformen. Under pågående anfall kan det være vanskelig rent praktisk å komme til med rektalvæsken. Hos noen vil rektalvæsken kunne ha en klystereffekt, slik at legemidlet renner ut igjen. Diazepamets relativt lange halveringstid kan være en fordel dersom pasienten har tendens til å få anfallsresidiv den første tiden etterpå, men for mange vil det være en ulempe at den sederende effekten sitter så lenge i. Den største ulempen er likevel at de fleste finner det ydmykende og sosialt uakseptabelt å bli gitt et legemiddel per rectum. Skolepersonell bør heller ikke belastes med å måtte gi medikamenter rektalt.

De siste årene har vi ved Epilepsisenteret-SSE gradvis erstattet rektal diazepam med bukkal midazolam (Epistatus). Voksne får 10-20 mg og barn $0,3 \mathrm{mg} / \mathrm{kg}$ (maksimalt $10 \mathrm{mg}$ ). Ved behov kan dosen gjentas etter ti minutter. Midazolam gitt bukkalt er enklere å administrere enn diazepam gitt rektalt (fig 1). I noen tilfeller vil stor spyttproduksjon kunne gi problemer, men da kan væsken dryppes i nesen. Noen klager over vond ettersmak i munnen. Midazolamets korte halveringstid gjør at pasienten bare er beskyttet mot anfall i 2-3 timer, men dette er for de fleste en fordel, ettersom den sederende effekten også varer kortere. Den største fordelen er imidlertid at pasienten slipper den krenkende rektale administreringen. Midazolam bukkal løsning må skaffes på registreringsfritak, men vår erfaring er at det er stabile leveranser og at NAV godkjenner forskrivning på blåresept på sosialt grunnlag.

Alle som har omsorg for personer med alvorlig epilepsi, for eksempel pårørende eller personale i omsorgsboliger, bør ha tilgang til en individuelt tilpasset plan om hva som bør gjøres hvis det oppstår en akutt situasjon, slik som serieanfall eller status epilepticus. De bør etter vårt skjønn utstyres med midazolamvæske. Til voksne bør det gis 10-20 mg bukkalt etter ca. fem minutter ved konvulsiv status epilepticus og etter ca. 20 minutter ved ikke-konvulsiv status epilepticus. Barn bør gis $0,3 \mathrm{mg} / \mathrm{kg}$ i tilsvarende situasjoner.

\section{Hovedbudskap}

- Ved epilepsi brukes benzodiazepinene hovedsakelig for anfallskupering

- I sykehus er intravenøs diazepam førstevalget ved serieanfall og status epilepticus

- Ved vedvarende anfallsaktivitet utenfor sykehus anbefaler vi midazolam gitt bukkalt fremfor diazepam gitt rektalt 

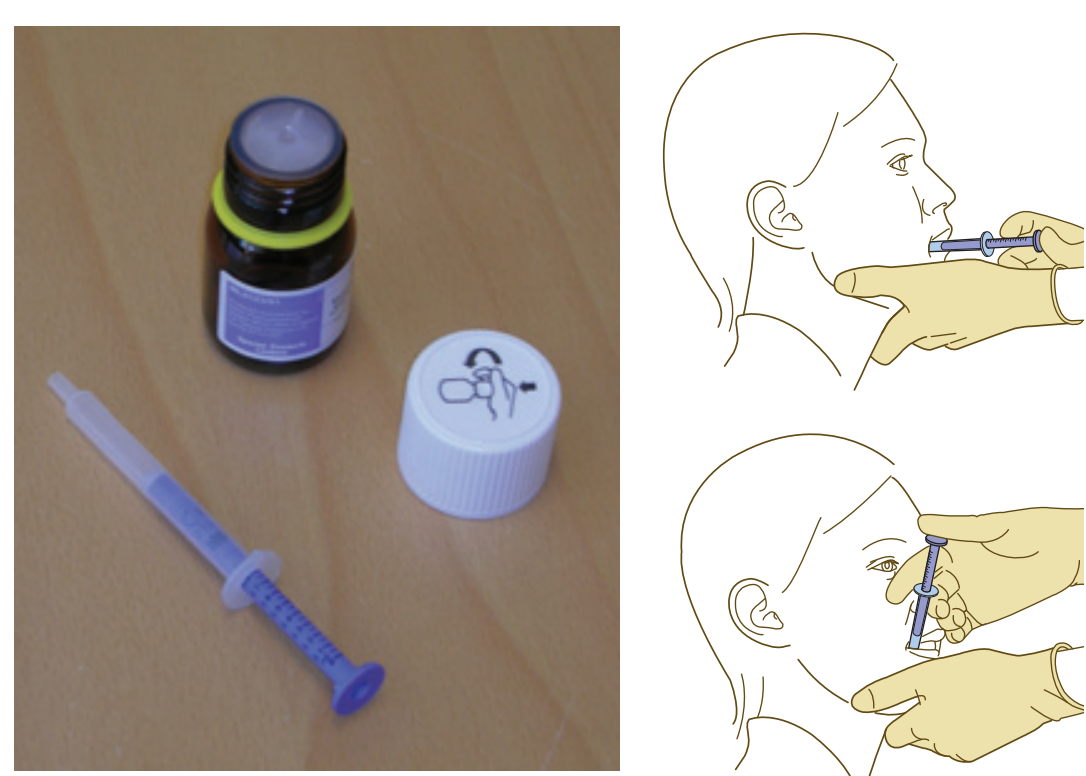

- Trekk opp forskrevet dose med sprøyten som følger med

- Dosen gis ved å føre sprøyten vannrett inn mellom kinn og tenner. Midazolam sprøytes nedover, inn mellom kinnet og nedre tannrekke

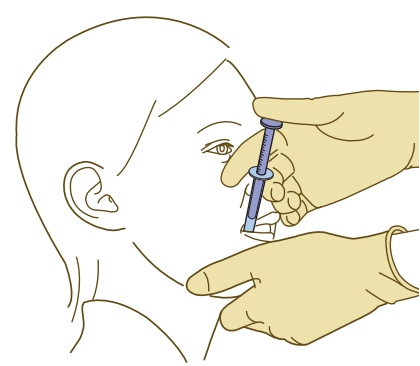

Sprøyt ca. halvparten på hver side slik at væsken ikke svelges

Ved stor spyttproduksjon kan midazolam eventuelt dryppes langsomt i nesen, ca. halvparten i hvert nesebor

Figur 1 Administrering av midazolamløsning gitt bukkalt

\section{Profylaktisk}

Toleranseutvikling, dvs. gradvis tap av den anfallsdempende effekten, og i noen grad bivirkninger, begrenser bruken av benzodiazepiner som anfallsprofylakse. Like fullt er klonazepam (Rivotril), klobazam (Frisium, må skaffes på registreringsfritak) og nitrazepam (Apodorm, Mogadon) noe brukt som tilleggspreparater hos pasienter med vanskelig kontrollerbare anfall av så vel partiell som generalisert type. 1,4-benzodiazepiner, slik som klonazepam, kan hos barn og utviklingshemmede gi tretthet, ustøhet, sikling, hyperaktivitet og andre atferdsforstyrrelser. Klobazam, som er det eneste 1,5-benzodiazepinet, har en større virkningsbredde enn klonazepam og er mindre nevrotoksisk. Skal man velge et benzodiazepin som anfallsprofylaktikum, er klobazam vårt førstevalg. Det til tross for at det gjort få velkontrollerte studier av klobazam ved epilepsi (7). I en prospektiv studie med 115 barn med refraktær epilepsi som fikk klobazam som tilleggsmedikament, ble $16 \%$ anfallsfrie og ytterligere $31 \%$ fikk mer enn $90 \%$ anfallsreduksjon. Etter en initial bedring utviklet $38 \%$ toleranse, dvs. den anfallsreduserende effekten ble gradvis borte (8). Særlig gunstig er klobazam hos pasienter med partielle anfall uten sekundær generalisering.

Nitrazepam blir hovedsakelig brukt som tilleggsmedikasjon hos barn med alvorlig epilepsi (9). Medikamentet har spesielt god effekt ved myoklonier i de første leveårene.

Enkelte trenger anfallsbeskyttelse bare i spesielle perioder, for eksempel kvinner med katamenial epilepsi (dvs. med menstruasjonsrelaterte anfall). Hos disse kan det være aktuelt å gi et benzodiazepin, for eksempel $20 \mathrm{mg}$ klobazam, om kvelden i en ukes tid med start noen dager før forventet menstrua- sjon. Noen har nytte av $5 \mathrm{mg}$ diazepam ved spesielle anledninger som bryllup e.l. Slik intermitterende behandling kan hindre toleranseutvikling.

Etter første tilfelle av feberkramper er det vanlig å forskrive diazepam rektalvæske som foreldrene kan bruke ved eventuelle nye feberkrampeanfall.

\section{Fordeler ved benzodiazepiner}

Benzodiazepinene har en svært god og rask anfallskuperende effekt ved mange anfallstyper (10). De finnes dessuten i flere administrasjonsformer. Det er gjort få studier der man har sammenliknet effekten av diazepam gitt rektalt med midazolam gitt bukkalt eller nasalt. En randomisert, kontrollert studie med 177 barn ved fire engelske sykehus viste at midazolam hadde en raskere anfallskuperende effekt enn diazepam, uten at tendensen til respirasjonshemming ble forsterket. Suksessraten og gjennomsnittlig tid for opphør av anfall var henholdsvis $56 \%$ og åtte minutter ved bruk av bukkal midazolam, mens tilsvarende tall for rektal diazepam var $27 \%$ og 15 minutter (11). Vår egen erfaring er at den anfallskuperende effekten av midazolam og diazepam er nokså lik hos voksne og hos barn.

For epilepsipasienter med mye angst kan benzodiazepinenes kombinerte antikonvulsive og anxiolytiske egenskaper være gunstig. Ved siden av god anfallskuperende effekt og lav toksisitet er midlene relativt billige.

\section{Ulemper ved benzodiazepiner}

Benzodiazepinene kan gi toleranseutvikling med gradvis avtakende anfallsreduserende effekt, både når de gis profylaktisk og ved anfallskupering. Gis benzodiazepiner svært ofte for anfallskupering, for eksempel flere ganger i uken, kan den svingende konsentrasjonen i blodet fremkalle nye anfall istedenfor å gi anfallsbeskyttelse (12). Gitt profylaktisk kan dessuten en rask dosenedtrapping eller seponering gi abstinenssymptomer og risiko for status epilepticus.

Benzodiazepiner kan svekke kardiorespiratorisk funksjon, særlig når de gis raskt intravenøst. Blodtrykksfall og respirasjonshemming kan da forekomme. Etter vår erfaring er dette sjelden et problem når medikamentet gis peroralt eller rektalt, med mindre det gis svært høye doser eller pasienten på forhånd har svekket hjerte- eller lungefunksjon.

Benzodiazepiner kan bli gjenstand for misbruk, men dette er et relativt sjeldent problem hos pasienter med epilepsi. Stoffenes sederende effekt kan gjøre det vanskelig å monitorere pasientens bevissthetsnivå, og noen klager over ubehagelige ettervirkninger. Hos enkelte med Lennox-Gastauts syndrom kan benzodiazepiner fremkalle toniske anfall.

\section{Oppsummering}

Toleranseutvikling, med gradvis tap av den anfallsbeskyttende effekten, er hovedgrunnen til at langtidsbruk av benzodiazepiner sjelden er aktuelt ved epilepsi. Hvis man likevel velger å bruke et benzodiazepin som anfallsprofylaktikum, anbefaler vi til voksne klobazam og til barn nitrazepam som tilleggspreparat, særlig til dem med bare partielle anfall uten sekundær generalisering. Hos pasienter med et fast og forutsigbart anfallsmønster kan intermitterende klobazameller diazepambehandling være aktuelt.

Ved behandling av serieanfall og status epilepticus i sykehus er intravenøs diazepam fortsatt førstevalget. Vi anbefaler midazolam gitt bukkalt som førstevalg utenfor sykehus, 
fordi effekt- og bivirkningsprofilen av dette midlet er minst like god som for diazepam og fordi bukkal administrasjon er langt å foretrekke fremfor rektal, både praktisk og sosialt.

Oppgitte interessekonflikter: Ingen

\section{Litteratur}

1. Sternbach LH, Fryer RI, Keller 0 et al. Quinazolines and 1,4-benzodiazepines, X: nitro-substituted 5-phenyl-1,4-benzodiazepines derivatives. J Med Chem 1963; 6: 261-5.

2. Gastaut H, Naquet R, Poire R et al. Treatment of status epilepticus with diazepam (Valium). Epilepsia 1965; 6: 167-82.

3. Macdonald RL, Angelotti TP. Native and recombinant $\mathrm{GABA}_{\mathrm{A}}$-receptor channels. Cell Physiol Biochem 1993; 3: 352-73.

4. Riss J, Cloyd J, Gates J et al. Benzodiazepines in epilepsy: pharmacology and pharmacokinetics. Acta Neurol Scand 2008; 118: 69-86.

5. Meldrum BS, Chapman AG. Benzodiazepine receptors and their relationship to the treatment of epilepsy. Epilepsia 1986; 27 (suppl 1): S3-S13.

6. Cock HR, Schapira AH. A comparison of lorazepam and diazepam as initial therapy in convulsive status epilepticus. QJM 2002; 95: 225-31.

7. Michael B, Marson AG. Clobazam as an add-on in the management of refractory epilepsy. Cochrane Database Syst Rev 2008; 2: CD004154.

8. Munn R, Farrell K. Open study of clobazam in refractory epilepsy. Pediatr Neurol 1993; 9: 465-9.

9. Chamberlain MC. Nitrazepam for refractory infantile spasms and the Lennox-Gastaut syndrome. J Child Neurol 1996; 11: $31-4$.

10. Treiman DM, Meyers PD, Walton NY et al. A comparison of four treatments for generalized convulsive status epilepticus. Veterans Affairs Status Epilepticus Cooperative Study Group. N Engl J Med 1998; 339: 792-8.

11. Mclntyre J, Robertson S, Norris E et al. Safety and efficacy of buccal midazolam versus rectal diazepam for emergency treatment of seizures in children; a randomised controlled trial. Lancet 2005; 366: $205-10$.

12. Brodtkorb E, Aamo T, Henriksen 0 et al. Rectal diazepam: pitfalls of excessive use in refractory epilepsy. Epilepsy Res 1999; 35: 123-33.

Manuskriptet ble mottatt 24.9. 2009 og godkjent 28.1. 2010. Medisinsk redaktør Åslaug Helland. 